\title{
Punishment of nonspecific responses: Does the negative half of the law of effect apply?
}

\author{
WILLIAM 0. BEAVERS and CHARLES C. PERKINS, JR. \\ Kansas State University, Manhattan, Kansas 66506
}

\begin{abstract}
Pigeons were trained to peck for food during red and to nonpeck during green. Response-independent shock was then introduced and shock intensity regularly increased between successive sessions. As shock increased, the birds' rate of pecking decreased to zero during green, but the rate of nonpecking failed to decrease. This result paralleled results reported by Rachlin and Herrnstein (1969) with a similar procedure except that shocks were response dependent. Therefore, their results do not demonstrate that a punishment contingency fails to weaken nonpecks.
\end{abstract}

In "Hedonism Revisited: On The Negative Law of Effect," Rachlin and Herrnstein (1969) conclude that specific responses (e.g., pigeons' keypecks) are weakened by punishment but that nonspecific responses (e.g., nonpecks) are not. They base their conclusion on the results of an experiment in which peck-dependent shocks during one stimulus decreased pecking but nonpeck-dependent shocks during another stimulus failed to decrease nonpecks. The present experiment provides a control for possible stimulus-shock effects which Rachlin and Herrnstein seem to have overlooked in interpreting the results of their experiment.

In Rachlin and Heernstein's (1969) experiment, pigeons were first reinforced with food on a variableinterval (VI) schedule for pecking in one component of a multiple schedule (red) and reinforced on the same VI schedule for nonpecking in the other component (green). After steady state responding was attained, response-dependent shocks were introduced on an independent VI schedule and shock intensity was increased between sessions. As the intensity of the shock was increased, the rate of pecking in red decreased eventually to zero, while the rate of nonpecking in green remained the same. Rachlin and Herrnstein concluded that nonpecking was not weakened by the negative half of the law of effect.

This conclusion fails to take into account possible effects of the stimulus-shock relationship. In conditioned suppression experiments with pigeons, a signal which indicates an increased probability of response-independent shock is superimposed on a baseline of keypecking for grain. During the signal the peck rate decreases (e.g., Hoffman, 1969). Because pecking and nonpecking are incompatible, a "conditioned suppression" or "conditioned emotional response" procedure may also

This research was supported by National Science Foundation Research Grant GB-27595. William Beavers is now at the University of Manitoba. Reprints may be obtained from Charles C. Perkins, Department of Psychology, Kansas State University, Manhattan, Kansas 66506. be said to increase the pigeon's tendency to nonpeck during the signal.

Presumably, a procedure in which response-dependent shocks are delivered may have both response-shock and stimulus-shock effects. When shock follows pecking, the two effects are mutually facilitative, i.e., responseshock and stimulus-shock effects are both conducive to a decrease in the rate of pecking. When shock follows nonpecking, i.e., nonpecking is punished, the responseshock and stimulus-shock effects are opposed. In this case, if the negative half of the law of effect applies, response-shock effects tend to decrease nonpecks (i.e., increase pecking). Presumably, the stimulus-shock effects (i.e., suppression) would tend to decrease pecking. The resultant behavior will be some combination of the two effects, seemingly a change in the direction of the stronger. Rachlin and Herrnstein (1969) appear to attribute the absence of any decrease in rate of nonpecking when shock follows nonpecks to a failure of the negative half of the law of effect to weaken nonpecks. That is, they conclude that shock does not punish nonpecks. We interpret this to mean that the nonpeck-shock relationship has no effect. However, they included no control for stimulus-shock effects. The present experiment provides such a control by replicating the critical features of Rachlin and Herrnstein's procedure, except that all shocks were response independent rather than response dependent.

\section{METHOD}

\section{Subjects}

Four experimentally naive pigeons obtained from a local breeder served as subjects.

\section{Apparatus}

Two identical singlekey Skinner boxes were used. Each box was $33 \times 32 \times 22.5 \mathrm{~cm}$. A Lehigh Valley Electronics grain feeder and a translucent Gerbrands response key were in the middle of the front panel. The key was $17 \mathrm{~cm}$ above the floor and required a force of $.09 \mathrm{~N}(9 \mathrm{~g})$ to activate it. Red and green $6.3-\mathrm{V}$ ac lights were positioned directly behind the key. A 7-W white houselight was located in the center of the ceiling. 
Tenth of a second ac shocks from source with a $10,000 \mathrm{ohm}$ resistor in series with the subject were delivered through stainless steel electrodes implanted around the pubis bone and attached to a harness (Azrin, 1959).

A ventilating fan and white noise provided an $80-\mathrm{dB}$ masking noise. Electromechanical control and recording equipment and a shock generator were located in an adjacent room.

\section{Procedure}

Birds were implanted with the electrodes while being reduced to $75 \%$ ad-lib weight. They were then magazine trained for 2 days. On Day 3 the birds were shaped to peck a white key. Reinforcement consisted of $4 \mathrm{sec}$ access to grain, during which the only illumination was from the feeder light. On Day 4 the birds received continuous reinforcement followed by increasingly sparse intermittent reinforcement, which culminated in VI 60 training on Day 6. The procedure initiated on Day 7 consisted of a multiple schedule in which there were successive 2-min presentations of red and green key lights. In the red component, pecks occasionally produced food and nonpecks cancelled any food reinforcement which had been set up. That is, if the pigeon failed to peck the key within 5 sec after reinforcement was primed, the food reinforcement was cancelled. A variableinterval (VI) 30-sec tape scheduled "events." A random $50 \%$ of the events were primings of food reinforcement to produce a VI 60-sec schedule of food reinforcement. The other half of the events were response-independent shocks resulting in a variable-time (VT) 60 -sec schedule of shock delivery. Shock presentation was not affected by the bird's behavior. During baseline training shocks were of zero intensity, i.e., shocks were null events. Except that the consequences of pecking and nonpecking were reversed, the same schedules were used in the green component. When the VI tape scheduled food during green, the next nonpeck ( 5 sec without a keypeck) produced food; if the bird pecked first, the food reinforcement was cancelled. If, however, shock was scheduled, it was delivered immediately regardless of the bird's behavior.

The schedule used is summarized in Table 1 along with the schedule employed by Rachlin and Herrnstein (1969). The words used in Table 1 to describe Rachlin and Herrnstein's schedules are equivalent to their description, though the terms differ.

Ten cycles of the multiple schedule were presented in each daily 40-min session. Food presentation was scheduled just as in Rachlin and Herrnstein's (1969) experiment. Scheduling of shock differed in the present experiment in that the shocks were response independent and could not be avoided.

Baseline responding was established by training with shocks of zero intensity until the subjects appeared to reach steady state. On the next session shocks were $15 \mathrm{~V}$. Between succeeding sessions, shocks were increased $5 \mathrm{~V}$, until keypecking was completely suppressed in the red component. (Rachlin and Herrnstein increased shock severity by changing amperage).

\section{RESULTS}

The mean rate for each bird over the last 4 days before introduction of the $15-\mathrm{V}$ shock was used as his

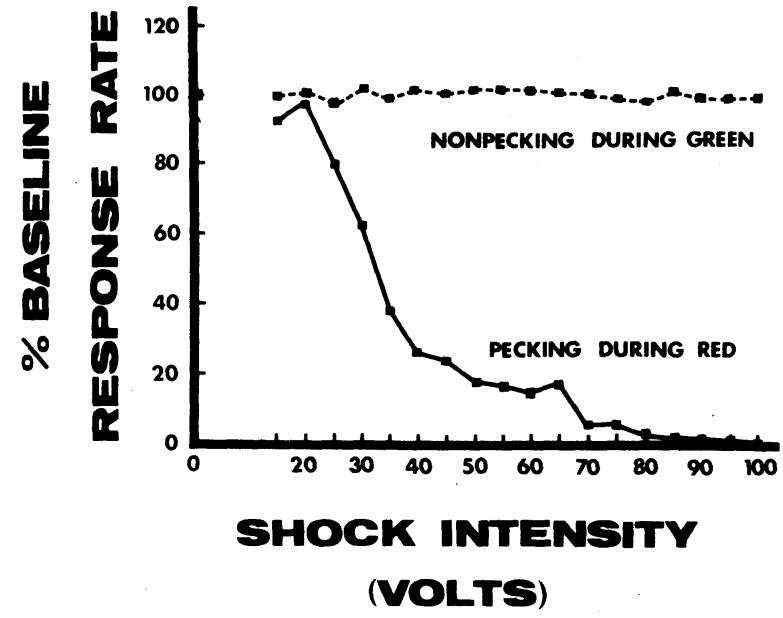

Figure 1. Median percentage of baseline response rate as a function of shock intensity. Baseline rates for pecking during red and nonpecking during green were established by computing the mean rate for each bird over the last 4 days of steady state before shock was introduced. The response measure for zero intensity is 100 by definition. All other points represent the median percentage of baseline for the four birds at each voltage setting.

baseline peck rate in red. During red baseline, peck rates for individual birds ranged from 42 to 83 responses/min. For three of the four birds, mean number of pecks during the $20 \mathrm{~min}$ of green in a baseline session was less than four. The other bird averaged 4.2 pecks/min during green. In short, at steady state prior to the introduction of shock; all birds keypecked at high rates during red and nonpecked at high rates during green.

Figure 1 summarizes the results in the same manner Rachlin and Herrnstein (1969) employed. The solid curve in Figure 1 represents a median value of the four birds' daily rate of pecking during red as a percentage of baseline rate. Each point after baseline represents a single session with shocks of the voltage indicated. This curve shows that as shock increased, rate of pecking during red declined to zero. The broken curve represents rate of nonpecking in green as a percentage of baseline rate. As the upper curve shows, nonpecking during green did not decrease as shock was increased. The results are essentially the same as Rachlin and Herrnstein's (1969). Apparently, response-independent shock weakened pecking in red but failed to weaken nonpecking in green.

Table 1

Schedules of Food and Shock Delivery

Experiment

Beavers and Perkins

Rachlin and Herrnstein 2-min Red Component

2-min Green Component

Peck VI 60 food, VT 60 shock

Nonpeck cancels food

Peck VI 60 food, Peck VI 60 shock Nonpeck cancels food or shock
Nonpeck VI 60 food, VT 60 shock

Peck cancels food

Nonpeck VI 60 food, Nonpeck VI 60 shock Peck cancels food or shock 


\section{DISCUSSION}

We are in full agreement with Rachlin and Herrnstein's (1969) conclusion that both halves of the law of effect are required to predict behavior. On the other hand, their conclusion that the negative half of the law of effect applies only to specific responses, such as pecking, and not to nonspecific responses, such as nonpecking, does not seem to be warranted. Our results indicate that, rather than being absent, the response-dependent effects of shock might have been counteracted by responseindependent effects.

Foree and Lolordo (1974) demonstrated that keypecking may be maintained by shock avoidance. Because pecks and nonpecks are incompatible, such shock avoidance by keypecking is equivalent to maintaining a reduced nonpeck rate by responsedependent (punishing) shock.

Williams and Williams (1969) employed an omission "negative automaintenance" procedure in which food followed a short stimulus on a response key whenever the key was not pecked. If the key was pecked during the stimulus, food presentation was omitted. Williams and Williams' birds keypecked on a large proportion of trials. An argument analogous to Rachlin and Herrnstein's (1969) would imply that avoidance of food reinforces pecking. However, consideration of the response-independent effects (autoshaping) suggests a different interpretation.

Taken as a whole, the results may be more parsimoniously explained by assuming that pecking tendencies are affected not only by the relative value of the stimuli which follow pecks and nonpecks but also by the effect of expectations on the relative value of the pecks and nonpecks themselves. Response-independent shock suppressed pecking, indicating that this response becomes aversive (relative to nonpecking) when shock is expected. Similarly, autoshaping (Brown \& Jenkins, 1968; Hearst \& Jenkins, 1974) indicates that, when a stimulus on the key signals food, keypecking has greater value than when the stimulus does not signal food. The strength of the tendency to keypeck seems to depend on both the value of pecking (relative to nonpecking) and the relative value of the outcomes of these two classes of responses. An approach to behavior change which emphasizes preferences for stimuli but ignores response preferences and the effects expectancies have on them (e.g., stimulusshock effects) is quite incomplete.

\section{REFERENCES}

Azrin, N. H. A technique for delivering shock to pigeons. Journal of the Experimental Analysis of Behavior, 1959, 2, 161-163.

Brown, P. L., \& Jenkins, H. M. Auto-shaping of the pigeon's keypeck. Journal of the Experimental Analysis of Behavior, 1968, 11, 1-8.

ForeE, D. D., \& Lolordo, V. M. Transfer of control of the pigeon's key peck from food reinforcement to avoidance of shock. Journal of the Experimental Analysis of Behavior, 1974, 22, 251-259.

HeARST, E., \& JENkins, H. M. Sign tracking: The stimulusreinforcer relation and directed action. Austin, Texas: The Psychonomic Society, 1974.

HofFMAN, H. S. Stimulus factors in conditioned suppression. In B. A. Campbell \& R. M. Church (Eds.), Punishment and aversive behavior. New York: Appleton-Century-Crofts, 1969. Pp. 185-234.

Rachlin, H., \& HerRnstein, R. J. Hedonism revisited: On the negative law of effect. In B. A. Campbell \& R. M. Church (Eds.), Punishment and aversive behavior. New York: AppletonCentury-Crofts, 1969. Pp. 83-109.

Williams, D. R., \& Williams, H. Automaintenance in the pigeon: Sustained pecking despite contingent nonreinforcement. Journal of the Experimental Analysis of Behavior, 1969, 12, 511-520.

(Received for publication August 12, 1976.) 